\title{
Changes in Mineral Profile and Morphological Traits of Pea (Pisum sativum L.) as Influenced by Fusarium oxysporum F. Sp. Pisi under Natural Conditions
}

\author{
Rana Muhammad Sabir Tariq ${ }^{1 *}$, Shahbaz Talib Sahi ${ }^{1}$, Tanveer Ahmad $^{2}$ and Abdul Hannan ${ }^{1}$ \\ ${ }^{1}$ Department of Plant Pathology, University of Agriculture, Faisalabad, Pakistan \\ ${ }^{2}$ Department of Horticultural Sciences, College of Agriculture, D. G. Khan, Pakistan
}

\begin{abstract}
Eight pea varieties including three commercial and five advance lines were cultivated under natural conditions for the infection of Pea wilt disease. Only four varieties were found susceptible to Fusarium wilt. Infected and healthy samples were collected from each variety. After pathogenecity of Fusarium oxysporum F. sp. pisi, the mineral and growth parameters from each sample were recorded. The parameters of healthy and infected samples were compared within each variety. Nitrogen was slightly increased $(21.09 \%)$ after the onset of infection. While infected samples showed a decline in Phosphorus (44.38\%), Potassium (53.64\%), Calcium (23.60\%), Magnesium (57.24\%), and Zinc (32.22\%). Growth parameters were also influenced negatively after the infection. They included fresh plant weight $(68.79 \%)$, dry plant weight $(57.29 \%)$, shoot length $(50.43 \%)$ and No. of pods/plant $(100 \%)$ while root length remained un-affected as compared to non-infected plants. These studies explained the role of vascular infection on the physiology and morphology of Pea.
\end{abstract}

Keywords: Pea wilt; Soil born; Vascular infection

\section{Introduction}

Pea is (Pisum sativum L.) fourth most important legume crop in the world [1]. Its importance can be estimated from the fact that, $40 \%$ of total pulse trade is based over pea [2] and it is important dietary source of proteins that is up to 15.5 to $39.7 \%$ of total biomass [3]. Apart from other constraints of pea production, the diseases play a significant role. Pea is infected by several pathogenic fungi in which Fusarium oxysporum F. sp pisi is significant causing wilt disease, that may cause partial to complete loss of crop [4,5].

Pea wilt disease is prevailing almost in all pea growing regions of the world. It was firstly reported by Linford in Wisconsin (U.S.A) in 1928 [6]. When the infection takes place it invades the root system and move upward through water conducting xylem tissues. In the result the plant becomes pale. Infection starts from lower leaves and gradually moves to the upper portion. Leaves and stipules show downward curling and plant growth is stunted. In severe cases, the plant wilts and dies due to vessel clogging. Generally pods are not formed, if pod formation occurs the seed is not well developed. Sometimes infected seed is formed which act as a secondary source of disease spread. Root system is not destroyed at all, sometimes remains unaffected in mild cases. Cross-section of root and basal stem shows brick red, orange or yellow the vascular discoloration depending upon the severity of infection and race type [7]. Optimum temperature for the disease development is $21-26^{\circ} \mathrm{C}$ [8].

When a pathogen attacks the plant, it exhibits some reflective changes in its physiology which ultimately affect the normal metabolic functions. Fusarium spp. is also known to cause various biochemical changes in the pea. A little work has been published on such changes and response of Plant to such infections e.g. Morkunas et al. [9] stated that, high carbohydrates level prevented the peas from the invasion of F. oxysporum F. sp. pisi and the activity of free radicals such as $\mathrm{Mn}^{+2}$ were extensively raised. Wit-Elshove and Fuchs [10] discovered that, Pisatin breakdown in pea is also increased with the infection of Fusarium oxysporum. In the same research it was explored that, malate dehydrogenase, Superoxide dismutase and Catalase were significantly raised after the infection was occurred.

Fusarium oxysporum also causes morphological changes in the host as described by Benedict [11] who conducted a research over multiple pea cultivars and found the correlation between soil temperature and disease development caused by various soil pathogens including Fusarium sp., Rhizoctonia sp. and Pythium sp. Data was recorded from growth parameters of seed weight, plant weight, plant height, preemergence and post emergence killing of seedlings. Infection generally influenced the all growth parameters and growth was retarded. Keeping in view the above mentioned facts, the research was designed to find out the further mineral and morphological changes which are associated with host-pathogen interaction.

\section{Materials and Methods}

\section{Pathogenecity test}

Eight pea varieties were sown in Faisalabad district of Pakistan. Only four varieties were found susceptible. After the onset of disease the highly infected plants were collected. Healthy samples were collected from the same treatment for the comparison.

Isolation of Fusarium oxysporum was done over PDA: Mycelia

*Corresponding author: Rana Muhammad Sabir Tariq, Phd Scholar, Department of Plant Pathology, University of Agriculture, Faisalabad, Pakistan, Tel: 092-3348154036; E-mail: Sabir_tariq@yahoo.com

Received: August 26, 2014; Accepted December 30, 2014; Published January 02, 2015

Citation: Tariq RMS, Sahi ST, Ahmad T, Hannan A (2015) Changes in Mineral Profile and Morphological Traits of Pea (Pisum sativum L.) as Influenced by Fusarium oxysporum F. Sp. Pisi under Natural Conditions. J Plant Pathol Microb 5: 244. doi:10.4172/2157-7471.1000244

Copyright: @ 2015 Tariq RMS, et al. This is an open-access article distributed under the terms of the Creative Commons Attribution License, which permits unrestricted use, distribution, and reproduction in any medium, provided the original author and source are credited. 
Citation: Tariq RMS, Sahi ST, Ahmad T, Hannan A (2015) Changes in Mineral Profile and Morphological Traits of Pea (Pisum sativum L.) as Influenced by Fusarium oxysporum F. Sp. Pisi under Natural Conditions. J Plant Pathol Microb 5: 244. doi:10.4172/2157-7471.1000244

Page 2 of 6

were abundant and ranged in color from white to pale violet. Macroconidia were medium length and slightly curved, relatively slender and thin walled generally contained 3 septations. While microconidia were Oval or kidney shaped without septation and Koch's postulates were confirmed by inoculating the same varieties sown in the sterilized soil in the pots. Wilts symptoms were pronounced on these plants. Later on these inoculated samples were used to re-isolate the same pathogen.

\section{Biochemical studies}

Oven drying: All samples were oven dried at $60^{\circ} \mathrm{C}$ overnight.

Grinding: Dry samples were ground to fine powder for their biochemical studies.

\section{Total nitrogen contents}

Total nitrogen in each sample was estimated according to the Kjeldahl's method [12] method No. 46-10.Two grams of each sample were put into the digestion tube. Twenty milliliters of conc. $\mathrm{H}_{2} \mathrm{SO}_{4}$ (98\%) and 2 capsules of digestion mixture (as catalyst) were added into the digestion tube. The digestion was done for 3-4 hours (till the contents attained transparent color). The digested material was cooled at room temperature and diluted to a final volume of $50 \mathrm{ml}$. The ammonia trapped in $\mathrm{H}_{2} \mathrm{SO}_{4}$ was liberated by adding $40 \% \mathrm{NaOH}$ solution by distillation. Thenit was collected in a flask containing $4 \%$ boric acid solution, possessing methyl indicator. It was titrated against standard $0.1 \mathrm{~N} \mathrm{H}_{2} \mathrm{SO}_{4}$ solution and quantity of Nitrogen contents was calculated in \%age.

\section{Mineral analysis}

All mineral parameters including $\mathrm{P}, \mathrm{K}, \mathrm{Mg}, \mathrm{Ca}$ and $\mathrm{Zn}$ were determined through Atomic Absorption Spectrophotometer and protocols were followed as described in AOAC [13]. One gram of sample was digested within $10 \mathrm{ml}$ of nitric acid and percholric acid (7:3) at $180-200^{\circ} \mathrm{C}$ till the transparent. These contents were further diluted to a volume of $100 \mathrm{ml}$ with double distilled water. Concentration of mineral contents was determined by running the diluted samples on Atomic Absorption Spectrophotometer (Model: Varian, AA-240, Victoria, Australia) using air acetylene flame.

\section{Morphological parameters}

Shoot length $(\mathrm{cm})$, Root length $(\mathrm{cm})$, Dry and Fresh plant weight (grams) and No. of pods/plant were recorded from healthy and infected plants after uprooting from soil.

\section{Statistical Analysis}

The experiment was laid out according to Randomized Complete Block Design (RCBD). The data of each parameter was subjected to statistical analysis and means from healthy and diseased samples was compared by using LSD test [14].

\section{Results and Discussions}

\section{Disease incidence}

Although Infection occurred in the late season (Figure 1) and the incidence was calculated as below;

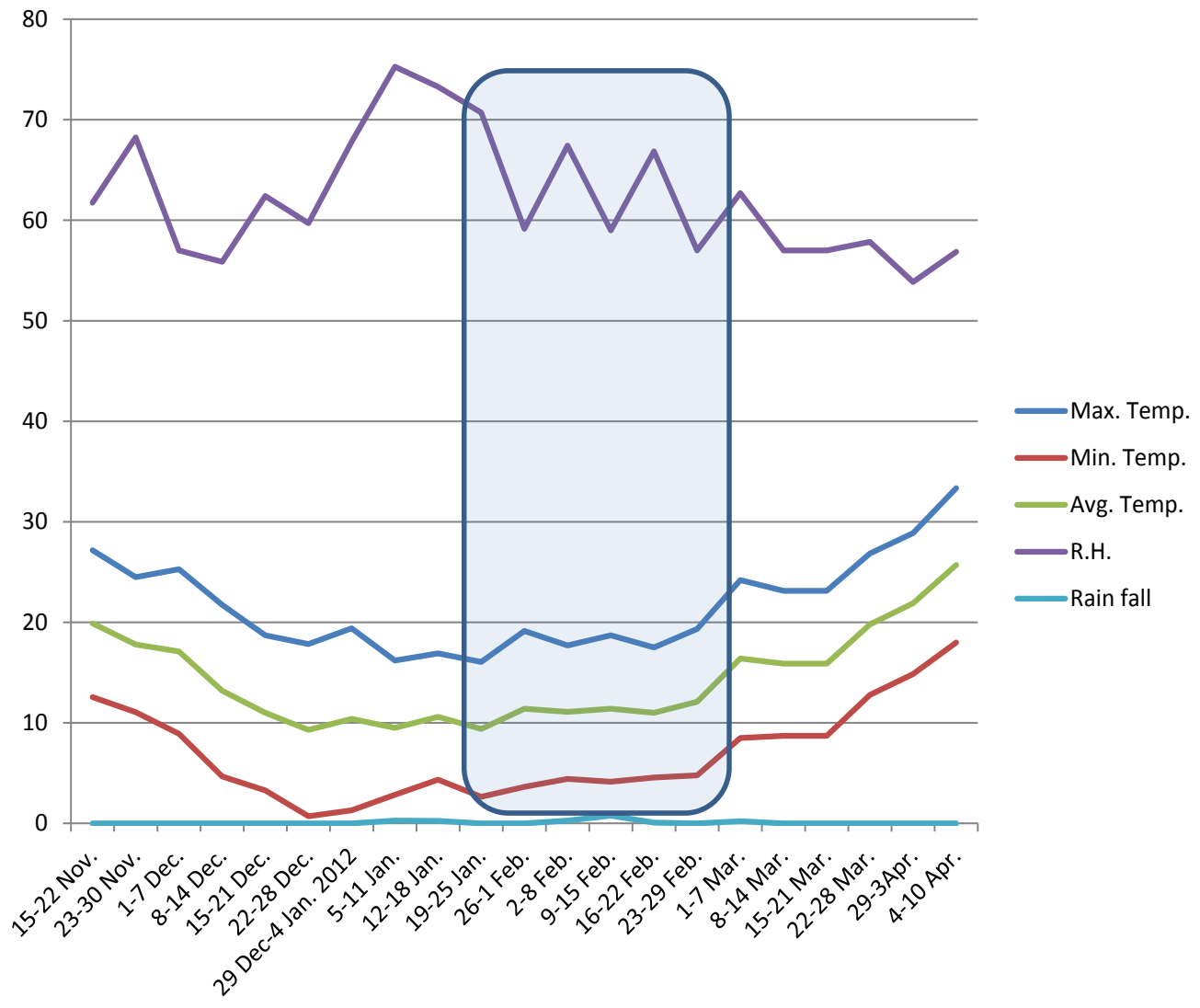

Figure 1: Meteorological conditions (2011-12) prevailing during the cultivation of Pea crop. 
Citation: Tariq RMS, Sahi ST, Ahmad T, Hannan A (2015) Changes in Mineral Profile and Morphological Traits of Pea (Pisum sativum L.) as Influenced by Fusarium oxysporum F. Sp. Pisi under Natural Conditions. J Plant Pathol Microb 5: 244. doi:10.4172/2157-7471.1000244

$$
\text { Disease incidence }=\frac{\text { No. infected plants }}{\text { Total no. of plants }} \times 100=35 / 642 \times 100=5.45 \%
$$

Screening test showed that only four varieties Euro, Early green, Advance line A(018337) and Advance line B (019309) were susceptible to Fusarium wilt, hence they were selected for biochemical and morphological comparisons.

\section{Changes in pea minerals after infection}

Mineral contents were compared among the varieties. Results have indicated that nitrogen was raised in all infected varieties particularly Adv. Line A (21.09\%). While there was significant reduction in Phosphorus (Adv. Line B; 44.38\%), Potassium (Early green; 53.64\%), Magnesium (Adv. line A; 57.24\%), Calcium (Euro; 23.60\%), and Zinc (Early green; $32.22 \%$ ) as compared to the healthy plants (Table 1 and Figure 2). That change might indicate the role of fungal mycelium over the translocation of the mineral elements after the vessel clogging.

\section{Morphological parameters}

As the results indicated (Table 2 and Figure 3) that Fusarium wilt caused significant reduction in the fresh weight (Euro; 68.79\%), Dry plant weight (Advance line B; 57.29\%), Shoot length (Adv. Line B; $50.43 \%$ ) and no. of pods/plant (Euro; $100 \%$ ) as compared to the healthy varieties. But the root length did not showed any significant change after the infection (Figure 3). Each variety has demonstrated varying response for each parameter, as shown in Table 2.

\section{Discussions}

Above mentioned facts are somewhere in accordance with previously documented facts of Pea wilt disease. Nitrogen contents were high within the infected samples. These findings agree with the previous work of Smiley et al. [15] studied the correlation of nitrogen application on the incidence of wilt pathogens F. roseum F. sp. Cerealis, F. solani F. sp. pisi and some saprophytic Fusarium species. Excess amount of nitrogen favored the infection. Similarly, in case of Nitrogen Burgt et al. [16] evaluated the effect of five organic sources of Nitrogen fertilizer on the growth of Fusarial infection of Head Blight of Wheat. These experiments also showed a positive correlation between the nitrogen and pathogen infestation. In case of Phosphorus, it was recorded in fewer amounts within the infected samples. Our studies are matching with the work of Yergeau et al. [17] who conducted a research on the ecological relationship of Fusarium sp. to the environmental factors. This experiment was conducted on Asparagus and Phosphorus was applied in different concentrations. After fertilizer application plants were inoculated with Fusarium sp. Fusarium infection was recorded more in the Phosphorus deficient plants and vice versa. Potassium was also studied in the healthy and infected plants. As our results indicated that low levels of Potash were recorded in infected samples as compared to the healthy ones, showing the influence of Fusarial infection which causing minimal availability to plant. Spiegel and Netzer [18] discussed the influence of different concentrations of Nitrogen and Potassium on Fusarium sp. and Root knot nematode (Meloidogyne javanica) singly or in combinations over the muskmelon plants. Parameters of infected plants were compared with healthy ones. These studies also stated that Potassium was depleted in the shoots after the onset of infection.

Calcium level was also reduced in the infected samples. Our results agreed with Blancand and Tramier [19]. They had sown the cuttings of carnation mother plants and six levels of Calcium were added to them. Experiments revealed that lower amount of calcium was favorable to the infection.

In case of Zinc contents, these findings are similar with the work

\begin{tabular}{|c|c|c|c|c|c|}
\hline Mineral parameters & SI. No. & Variety & Healthy & Infected & $\%$ Decrease after infection \\
\hline \multirow{4}{*}{ Nitrogen } & 1 & Euro & $3.967 \mathrm{a}$ & $4.576 \mathrm{a}$ & -15.37 \\
\hline & 2 & Early Green & $4.266 \mathrm{a}$ & $5.100 \mathrm{a}$ & -19.57 \\
\hline & 3 & Advance line A (No. 018337) & $4.033 \mathrm{a}$ & $4.883 \mathrm{a}$ & $-21.09^{\star *}$ \\
\hline & 4 & Advance line B (No. 019309) & $4.333 \mathrm{a}$ & $4.940 \mathrm{a}$ & -14.01 \\
\hline \multirow{4}{*}{ Phosphorus } & 1 & Euro & $4.96 \mathrm{a}$ & $2.90 \mathrm{a}$ & 41.53 \\
\hline & 2 & Early Green & $3.97 \mathrm{~b}$ & $2.70 a b$ & 31.81 \\
\hline & 3 & Advance line A (No. 018337) & $4.80 \mathrm{a}$ & $2.96 \mathrm{a}$ & 38.33 \\
\hline & 4 & Advance line B (No. 019309) & $3.83 \mathrm{~b}$ & $2.13 b$ & $44.38^{* *}$ \\
\hline \multirow{4}{*}{ Potassium } & 1 & Euro & $19.53 \mathrm{a}$ & $12.73 \mathrm{a}$ & 34.82 \\
\hline & 2 & Early Green & $19.33 \mathrm{a}$ & $8.96 \mathrm{a}$ & $53.64^{* *}$ \\
\hline & 3 & Advance line A (No. 018337) & $17.80 \mathrm{~b}$ & $11.60 \mathrm{a}$ & 34.83 \\
\hline & 4 & Advance line B (No. 019309) & $19.16 \mathrm{a}$ & $12.46 \mathrm{a}$ & 34.97 \\
\hline \multirow{4}{*}{ Magnesium } & 1 & Euro & $2.03 \mathrm{c}$ & $0.793 \mathrm{c}$ & 52.21 \\
\hline & 2 & Early Green & $2.33 \mathrm{~b}$ & $1.126 \mathrm{~b}$ & 51.93 \\
\hline & 3 & Advance line A (No. 018337) & $2.76 \mathrm{a}$ & $1.186 \mathrm{~b}$ & $57.24^{\star \star}$ \\
\hline & 4 & Advance line B (No. 019309) & $2.43 \mathrm{~b}$ & $1.660 \mathrm{a}$ & 31.68 \\
\hline \multirow{4}{*}{ Calcium } & 1 & Euro & $2.966 \mathrm{~b}$ & $2.266 \mathrm{~b}$ & $23.60^{* *}$ \\
\hline & 2 & Early Green & $3.466 \mathrm{a}$ & $3.000 \mathrm{a}$ & 13.44 \\
\hline & 3 & Advance line A (No. 018337) & $3.333 \mathrm{a}$ & $3.000 \mathrm{a}$ & 10.0 \\
\hline & 4 & Advance line B (No. 019309) & $3.600 \mathrm{a}$ & $3.200 \mathrm{a}$ & 11.11 \\
\hline \multirow{4}{*}{ Zinc } & 1 & Euro & $0.027 \mathrm{ab}$ & $0.0197 a b$ & 27.03 \\
\hline & 2 & Early Green & $0.027 \mathrm{ab}$ & $0.0183 a b$ & $32.22^{\star *}$ \\
\hline & 3 & Advance line A (No. 018337) & 0.029 a & $0.0240 \mathrm{a}$ & 17.24 \\
\hline & 4 & Advance line B (No. 019309) & $0.024 \mathrm{~b}$ & $0.0177 \mathrm{~b}$ & 26.25 \\
\hline
\end{tabular}

Level of significance $=\alpha=0.05$, Critical $\mathrm{T}$ Value $=2.447$

Means followed by same letters are not significantly different from one another according to Fisher's LSD test at $5 \%$ level of Significance.

Table 1: All pairwise LSD comparison of mineral profile of healthy and infected pea plants. 
Citation: Tariq RMS, Sahi ST, Ahmad T, Hannan A (2015) Changes in Mineral Profile and Morphological Traits of Pea (Pisum sativum L.) as Influenced by Fusarium oxysporum F. Sp. Pisi under Natural Conditions. J Plant Pathol Microb 5: 244. doi:10.4172/2157-7471.1000244

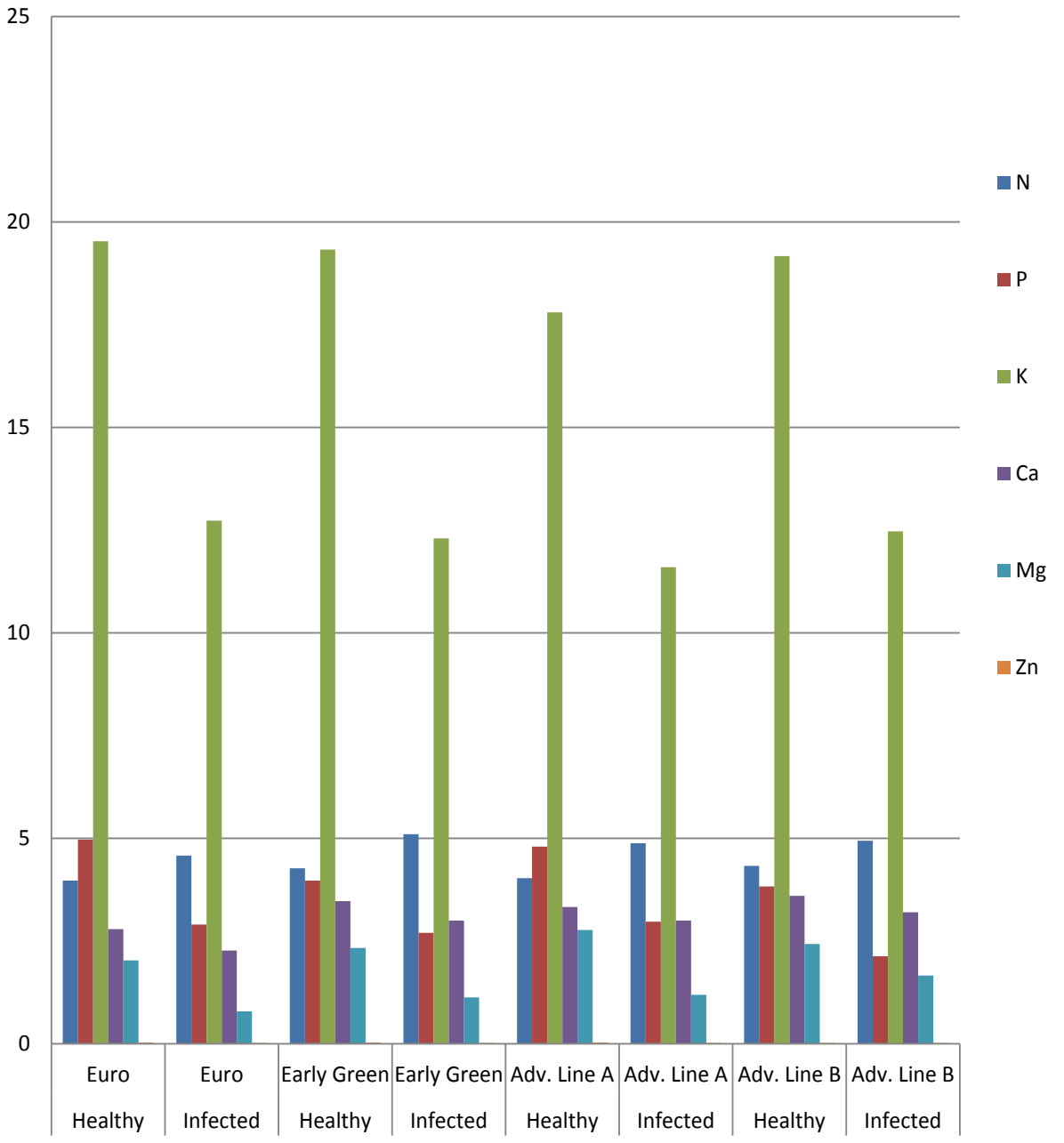

Figure 2: Comparison of Mineral profile of Healthy and infected Pae Varieties (\% of total Dry matter).

\begin{tabular}{|c|c|c|c|c|c|}
\hline $\begin{array}{l}\text { Morphological } \\
\text { Parameters }\end{array}$ & SI. No. & Variety & Healthy & Infected & $\%$ Decrease after infection \\
\hline \multirow{4}{*}{ Fresh Plant Weight } & 1 & Euro & $30.76 \mathrm{a}$ & $9.60 \mathrm{a}$ & 68.79 \\
\hline & 2 & Early Green & $28.93 \mathrm{a}$ & $11.06 \mathrm{a}$ & 61.78 \\
\hline & 3 & Advance line A (No. 018337) & $21.06 \mathrm{a}$ & $4.16 \mathrm{a}$ & $80.24^{* *}$ \\
\hline & 4 & Advance line B (No. 019309) & $12.20 \mathrm{a}$ & $4.86 \mathrm{a}$ & 60.16 \\
\hline \multirow{4}{*}{ Dry Plant Weight } & 1 & Euro & $11.40 \mathrm{a}$ & $8.68 \mathrm{a}$ & 23.85 \\
\hline & 2 & Early Green & $8.63 \mathrm{ab}$ & $9.83 \mathrm{a}$ & -13.90 \\
\hline & 3 & Advance line A (No. 018337) & $4.23 \mathrm{~b}$ & $2.26 \mathrm{a}$ & 46.57 \\
\hline & 4 & Advance line B (No. 019309) & $7.33 \mathrm{ab}$ & $3.13 \mathrm{a}$ & $57.29^{* \star}$ \\
\hline \multirow{4}{*}{ Shoot Length } & 1 & Euro & $71.10 \mathrm{a}$ & $38.20 \mathrm{a}$ & 46.27 \\
\hline & 2 & Early Green & $73.73 \mathrm{a}$ & $45.43 \mathrm{a}$ & 38.38 \\
\hline & 3 & Advance line A (No. 018337) & $48.80 \mathrm{a}$ & $48.40 \mathrm{a}$ & 0.4 \\
\hline & 4 & Advance line B (No. 019309) & 37.63 a & $37.63 \mathrm{a}$ & $50.43^{* *}$ \\
\hline \multirow{4}{*}{ Root Length } & 1 & Euro & $21.36 \mathrm{a}$ & $20.20 \mathrm{a}$ & $5.43^{* *}$ \\
\hline & 2 & Early Green & $18.13 a b$ & $18.56 \mathrm{a}$ & -2.37 \\
\hline & 3 & Advance line A (No. 018337) & $18.96 \mathrm{ab}$ & $19.03 \mathrm{a}$ & -0.37 \\
\hline & 4 & Advance line B (No. 019309) & $14.83 \mathrm{~b}$ & $14.10 \mathrm{~b}$ & 4.92 \\
\hline \multirow{4}{*}{ No. of Pods/Plant } & 1 & Euro & $6.00 \mathrm{a}$ & $0.0 \mathrm{a}$ & $100^{* *}$ \\
\hline & 2 & Early Green & $6.33 a$ & $1.66 \mathrm{a}$ & 73.77 \\
\hline & 3 & Advance line A (No. 018337) & $4.66 \mathrm{a}$ & $2.00 \mathrm{a}$ & 57.08 \\
\hline & 4 & Advance line B (No. 019309) & $8.00 \mathrm{a}$ & $2.66 \mathrm{a}$ & 66.75 \\
\hline
\end{tabular}

Level of significance $=\alpha=0.05$, Critical $\mathrm{T}$ Value $=2.447$

Means followed by same letters are not significantly different from one another according to Fisher's LSD test at $5 \%$ level of Significance.

Table 2: All pairwise LSD comparison of morphological parameters of healthy and infected pea plants. 
Citation: Tariq RMS, Sahi ST, Ahmad T, Hannan A (2015) Changes in Mineral Profile and Morphological Traits of Pea (Pisum sativum L.) as Influenced by Fusarium oxysporum F. Sp. Pisi under Natural Conditions. J Plant Pathol Microb 5: 244. doi:10.4172/2157-7471.1000244

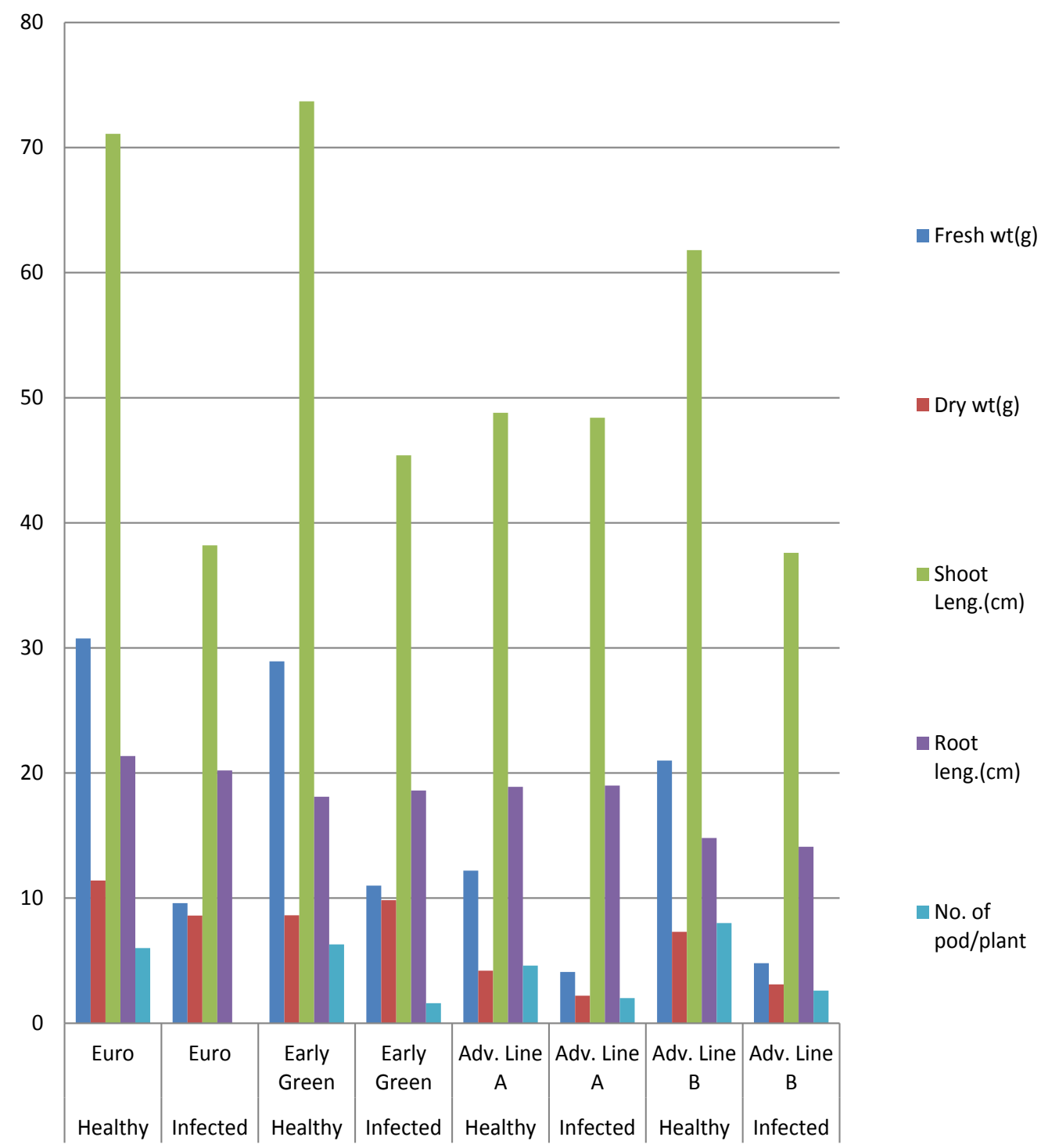

Figure 3: Comparison of Morphological parameters of Healthy and infected Pae Varieties.

of Soshi et al. [20]. They found the influence of Non-pathogenic strains of Fusarium sp. on the uptake of different soil elements in tomato. In this research $\mathrm{Zn}$ uptake was slightly reduced in few treatment as compared to healthy control. Morphological parameters of shoot length, shoot weight, root weight and No. of pods/plant were reduced after the infection. Al-Askar and Rashad [21] conducted a research find out the role of Arbuscular Mycorrizal (AM) fungi to check the growth of Fusarium sp. in the common beans under natural conditions. These fungi also enhanced the growth parameters as compared to untreated control plants. Shah et al. [22] discussed the pathogenic influence of certain fungi and Bacteria on the growth of the Fenugreek (Trigonellafoenum-graecum L). This impact was relevant to infection and plant growth parameters were reduced after the infection. Sartaj et al. [23] conducted an experiment for the biological control of tomato wilt disease caused by F. oxysporum. Penicillium sp. and Plant growth promoting fungi was taken as biocontrol agents. Untreated infected plants significantly declined their shoot and root weight. While Healthy plants remained unaffected.

\section{Conclusion}

Above mentioned research has given the major conclusion that Fusarium oxysporum causes significant changes in the physiology and morphology of plant. Even the disease was occurred late in the season but mineral uptake was strongly influenced by infection. Morphological parameters were also minimized. These changes showed the role of vascular infection on the mineral translocation of plant.

\section{References}

1. Hulse JH (1994) Nature, composition and utilization of food legumes. In Muehlbauer FJ, WJ Kaiser (eds.), Expanding the Production and Use of Cool Season Food Legumes. Kluwer Academic Publishers. Dordrecht, The Netherlands 77-97.

2. Oram PA, Agcaoili M (1994) Current status and future trends in supply and demand of cool season food legumes. In: Summerfield RJ (ed.), World Crops: Cool Season Food Legumes. Kluwer Academic Publishers, Dordrecht, The Netherlands, p. 3-49.

3. Bressani R, Elias LG (1988) Seed quality and nutritional goals in pea, lentil, faba bean and chickpea breeding. In: Summerfield RJ (ed.) World Crops: 
Citation: Tariq RMS, Sahi ST, Ahmad T, Hannan A (2015) Changes in Mineral Profile and Morphological Traits of Pea (Pisum sativum L.) as Influenced by Fusarium oxysporum F. Sp. Pisi under Natural Conditions. J Plant Pathol Microb 5: 244. doi:10.4172/2157-7471.1000244

Cool Season Food Legumes. Kluwer Academic Publishers, Dordrecht, The Netherlands, pp. 381-404

4. Basu PK, Crete R, Donaldson AG, Gourley CO, Haas JH, et al. (1973) Prevalence and severity of diseases of processing peas in Canada, 1970-71. Canadian Plant Disease Survey 53: 49-57.

5. Persson L, Bodker L, Wikstrom ML (1997) Prevalence and pathogenicity of foot and root rot pathogens of pea in Southern Scandinavia. Plant Disease 81 : 171-174.

6. Linford MB (1928) A Fusarium wilt of peas in Wisconsin. Wis Agr Expt Sta Res Bul 85.

7. Davidson RM, Byther RS, Haglund WA (1991) Extension Bulletin 1262: Pea wilt and Pea root rots in the home garden. College of Agriculture and Home Economics, Pullman, Washington.

8. Hagedorn DJ (1991) Handbook of Pea diseases. Cooperative extension publications, University of Wisconsin-extension, USA

9. Morkunas I, Bednarski W, Kopyra M (2008) Defense strategies of pea embryo axes with different levels of sucrose to Fusarium oxysporum and Ascochyta pisi. Physiol Mol Plant Pathol 72: 167-178.

10. Wit-Elshove AD, Fuchs $A$ (1971) The influence of the carbohydrate source on pisatin breakdown by fungi pathogenic to pea (Pisum sativum). Physiol. Plant Pathol 1: 17-24.

11. Benedict WG (1969) Influence of soil temperature on the development of pea root rot, Canadian Journal of Botany 47: 567-574.

12. AACC (2000) Approved Methods of American Association of cereal Chemists The Am Assoc Cereal Chem Inc, St. Paul. Minnesota.

13. AOAC (1990) Officials Methods of Analysis (15th edition). The Association of the Official Analytical Chemists. Arlington, Virginia, USA.

14. Steel RGD, Torrie JH (1997) Principles and procedures of statistics: A biometrical approach. 3rd ed. McGraw-Hill, New York.
15. Smiley RW, Cook RJ, Papendick RI (1971) Fusarium Foot Rot of Wheat and Peas as Influenced by Soil Applications of Anhydrous Ammonia and AmmoniaPotassium Aside Solutions. Phytopathology 62: 86-91.

16. Burgt GHM, Timmermans BGH, Scholberg J, Osman AM (2011) Effects of nitrogen application on grain nitrogen content, deoxinivalenol contamination and weeds in organic wheat. NJAS - Wageningen Journal of Life Sciences: 123-129.

17. Yergeau E, Sommerville DW, Maheux E, Vujanovic V, Hamel C, et al. (2006) Relationships between Fusarium population structure, soil nutrient status and disease incidence in field-grown asparagus. FEMS Microbiol Ecol 58: 394-403.

18. Spiegel Y, Netzer D (1984) Effect of nitrogen form at various levels of potassium, on the Meloidogyne-Fusarium wilt complex in muskmelon. Plant and Soil 81: 85-92.

19. Blanc D, Tramier $R$ (1980) Influence of the calcium nutrition of the carnation mother plant on the susceptibility of cuttings to Fusarium oxysporum $\mathrm{f}$. $\mathrm{sp}$. dianthi. Comptes Rendus des Seances de l'Academied'Agriculture de France 66: $532-538$

20. Soshi T, Enomoto S, Yamaguchil (2001) Effect of nonpathogenic Fusarium strains on the uptake rate of radionuclides by tomato. RIKEN Review 35.

21. Al-Askar AA, Rashad YM (2010) Arbuscular Mycorrhizal Fungi: A biocontrol agent against common Bean Fusarium Root Rot disease. Plant Pathology Journal 9: 31-38.

22. Shah MH, Khan SN, Tahira JJ, Sulman R, Anwar W, et al. (2010) Impact of pathogenic fungi and bacteria on Fenugreek (trigonellafoenum-graecumL.) plant stand quality under natural condition. Pakistan Journal of Phytopathology 22: $130-134$.

23. Sartaj AS, Sakamoto K, Inubushi K (2011) Effect of Penicillium sp. EU0013 inoculation on tomato growth and Fusarium wilt. Hort Research 65: 69-73. 